\title{
STATUS JEZIKA ZA POSEBNE I AKADEMSKE NAMENE U VISOKOM OBRAZOVANJU U SRBIJI
}

Marijana Prodanović

Univerzitet Singidunum,

Beograd, Srbija

Odgovorno lice:

Marijana Prodanović

e-pošta:

mprodanovic@singidunum.ac.rs

\section{Rezime:}

Savremeno tržište rada, ali i savremeni oblici poslovanja, u potrazi su za pojedincima koji poseduju ne samo veštine i znanja potrebne za uspešno bavljenje odabranom profesijom, no i one koje se odnose na jezičke obrasce koji se vezuju za datu profesiju, odnosno - jezik struke, a čija upotreba, bez sumnje, dovodi do uspešnije komunikacije u vezi sa svim pitanjima koje data struka postavlja ili na koja odgovara. Upravo iz tog razloga, ne bi li odgovorili na sve zahteve kojima su okruženi, očekuje se da obrazovne institucije, koje su deo sistema visokog obrazovanja, svojim diplomcima, pored znanja i veština u vezi sa užim stručnim oblastima, za koje su se opredelili, omoguće i sticanje znanja u vezi sa jezikom za posebne ili akademske namene. Ovaj rad teži osvetljavanju statusa engleskog, kao stranog jezika, na univerzitetima u Srbiji, sa posebnim osvrtom na status jezika za posebne i akademske namene. Pored toga što ilustruje trenutnu praksu, a u vezi sa izučavanjem i podučavanjem navedenih fenomena u sistemu visokog obrazovanja u Srbiji, rad upoređuje navedenu praksu sa modelima koji se primenjuju u zemljama iz okruženja, dok, u zaključku, navodi svojevrsne predloge, koji se odnose na pristup, kao i potrebe jezika struke, odnosno - jezika za akademske namene.

Ključne reči:

jezik za posebne namene, jezik za akademske namene, podučavanje jezika, sistem visokog obrazovanja, Srbija.

\section{UVOD}

Druga polovina dvadesetog veka posvedočila je rasprostranjivanju jezika za posebne namene, fenomenu koji je postao deo oblasti učenja i nastave jezika u celosti bez prethodnog planiranja, odnosno - kao rezultat potreba svih onih poslovnih ljudi, koji su želeli da svoju komunikaciju na stranom jeziku prilagode potrebama svoje struke [1, str. 5] dok se njegov uticaj, u okvirima nastave stranog jezika, u proteklim decenijama sve više širi. Kao rezultat, danas se susrećemo sa širokim spektrom svojevrsnih posebnih namena - a u okvirima nastave, odnosno učenja stranog jezika - kao što su: jezik prava, medicine, ekonomije (uključujući različite, specifičnije oblasti, poput - bankarstva, računovodstva, revizije, ljudskih resursa, reklamiranja i sl.), elektrotehnike, turizma, itd. Svakako, koncept jezika za posebne namene teži praćenju i odgovaranju na potrebe savremenog tržišta, te je gotovo izvesno da će se njegovi oblici 
i spektar profesija, odnosno stručnih oblasti koje uključuje - menjati na način na koji se menjanju okolnosti u kojima se nalaze i rade svi oni koji takav jezik izučavaju ili usvajaju.

Fenomenu jezika za posebne namene pridružio se i fenomen (primarno engleskog) jezika za akademske namene, čiji je cilj da pojedincu ukaže na važnost upotrebe adekvatnih jezičkih obrazaca u akademskom okruženju, te da, $\mathrm{u}$ isto vreme, pomogne proces studiranja ili, pak, istraživačke prakse, posebno kada su u pitanju procesi koji se realizuju na jeziku koji datom govorniku nije maternji. Jezik za akademske namene, nekada samo jedan od segmenata oblasti jezika za posebne namene, tokom proteklih decenija uspeo je da se se izbori za samostalniju poziciju u okvirima nastave i učenja/usvajanja jezika - ali i da brojne savremene izučavaoce jezika ubedi u opravdanost svoga postojanja. Danas su, kako jezik za posebne, tako i jezik za akademske namene pojmovi od značaja, koji se izučavaju ne samo kao sporedan, na svojevrastan način - pomoćni deo nastavnih planova, no su to oblasti kojima su posvećeni posebni kursevi, seminari, ali i celokupni studijski programi, namenjeni, s jedne strane, podučavanju istih, a s druge strane, njihovom usvajanju.

Upravo ne bi li svoje studente učinili što konkurentnijim na tržištu rada, ali i samostalno odgovorili svim zahtevima savremenog društva, visokoškolske ustanove, širom sveta, bez obzira na oblasti delovanja kojima se bave, sve više se odlučuju za to da u svoje nastavne planove i programe uvrste, najpre, jezik za posebne, ali i jezik za akademske namene, težeći tome da pojedinci, po diplomiranju, poseduju ne samo znanja i veštine u vezi sa strukom u vezi sa kojom su se obrazovali, no i jezikom, odnosno jezičkim pojmovima koji su, takođe, neodvoji deo date stručne oblasti.

\section{JEZIK ZA OPŠTE, POSEBNE ILI AKADEMSKE NAMENE}

Uzimajući u obzir činjenicu da je engleski jezik, bez sumnje, lingua franca savremenog sveta, ne čudi to što su upravo engleski jezik za posebne i akademske namene one oblasti koje, u okvirima dva navedena koncepta, zauzimaju vodeću poziciju. Kako je već naglašeno, prilike u svetu, a nakon Drugog svetskog rata, doveli su potrebe za obimnijom i bržom razmenom informacija u vezi sa pitanjima iz oblasti, kako trgovine, tako i nauke i tehnike - i to na međunarodnom nivou [1, str. 7], što je koncept engleskog jezika za posebne namene stavilo na posebno mesto, koje mu i danas, iz istih razloga - a to su interkulturalna komunikacija u vezi sa stručnim pitanjima, pripada.
Imajući u vidu srodnosti među osobenostima jezika za akademske, s jedne strane, i jezika za posebne namene, s druge strane, odnosno njihovu težnju da svoju primenu pronađu ne samo u akademskom okruženju, no i poslovnom okruženju u kojem će se, po diplomiranju, naći pojedinci koji su ih izučavali u okviru svojih obrazovnih institucija, neretko se dešava da se ova dva pojma, jednim delom, posmatraju kroz istu prizmu, dok valja napomenuti da, bez obzira na navedene srodnosti, postoje autori koji zagovaraju njihovu eksplicitniju diferencijaciju - i kada je u pitanju sama nomenklatura, ali i pristupi izučavanju.

Zapravo, kada su u pitanju posebne namene i jezik u takvim okvirima, neretka je, pored navedene, i klasifikacija koja uključuje, odnosno - razlikuje i (engleski) jezik za potrebe posla/struke (eng. English for Vocational/ Occupational Purposes), te jezik za potrebe obrazovanja (eng. English for Educational Purposes). U zavisnosti od njihove strukture i pristupa njihovom izučavanju, ovakvi segmenti jezika nalaze svoju primenu, kako za vreme obrazovanja, tako i nakon istog - u stvarnom poslovnom okruženju, kao ilustruje i slika koja sledi:

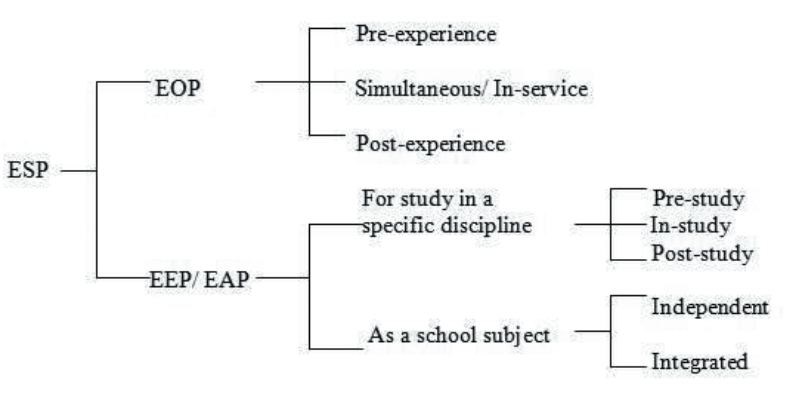

Fig. 1. Prikaz klasifikacije engleskog jezika za posebne namene (preuzeto: [2, str. 6])

Status engleskog jezika u svetu, te njegova, nedvosmisleno dominantna, upotreba, a kada je u pitanju realizacija nastavnih aktivnosti, u okviru studijskih programa koji su međunarodnog karaktera i teže svojevrsnoj mobilnosti studenata, zasigurno je uticao i na rasprostranjenost engleskog jezika za posebne/akademske namene.

U savremenom društvu, brojni su univerziteti širom sveta koji svoje studijske programe čine dostupnim ne samo studentima koji su pripadnici datog govornog područja, no i studentima koji dolaze iz svih krajeva sveta - a upravo je engleski jezik onaj jezik na kojem se, u takvim slučajevima, programi i realizuju. U takvim okolnostima - okolnostima koje, nesumnjivo, uključuju 
susrete među kulturama, te kulturološka kretanja i preplitanja, koje su dovele do značajnog broja onih koji studiraju na engleskom jeziku - engleski jezik (najpre) za akademske namene pronalazi svoju pravu i celovitu primenu, te možemo reći da je njegov trenutni položaj uslovila upravo globalizacija visokog obrazovanja [3, str. 2].

S jedne strane, usvajanje, učenje i podučavanje tzv. jezika za opšte namene je proces koji, za brojne nastavnike i one koji uče jezik, širom sveta, podrazumeva srodne aktivnosti. Jezik za opšte namene, ili tzv. opšti jezik (eng. general language) oduvek je imao za cilj osposobljavanje učenika za procese efektive pisane i usmene komunikacije - odnosno za, u različitim oblicima - veštinu pisanja, čitanja, slušanja i govorenja. U zavisnosti od potreba nastavnih grupa sa kojima rade, te u zavisnosti od sopstvenih modela koje prate - nastavnici stranog jezika se, decenijama unazad, odlučuju za najrazličitije metode ili, pak, njihove kombinacije - među kojima su, neizostavno, sugestopedija (enng. suggestopedia), direktni metod (eng. direct method), gramatičko-prevodni metod (eng. grammar-translation method), audiolingvalni metod (audio-lingual method), učenje jezika u zajednici (eng. community language learning), prirodni pristup (eng. natural approach), TPR metod (eng. total physical response) i dr [4].

Svakako, u zavisnosti od nivoa poznavanja jezika pojednica/grupe, nastavnici se, takođe, odlučuju i za najrazličitije nastavne materijale - izdavača sa tla zemalja u kojima je engleski jezik maternji, ali i izdavača iz zemalja u kojima se jezik usvaja i uči kao drugi ili strani jezik posredstvom kojih nastoje da oplemene kako receptivna, tako i produktivna znanja onih koji jezik uče/usvajaju. Na ishode, odnosno uspešnost procesa nastave jezika, zasigurno može uticati i upotreba nastavnih sredstava - dok sinergija navedenog, svakako, jeste jedan od značajnih faktora, a u okvirima same motivacije učenika.

Međutim, i sami procesi vezani za jezik za opšte namene, neretko, uključuju brojne izazove sa kojima se susreću i nastavnici i oni koje podučavaju - neke od njih mogu biti razlike u stilovima učenja, grupe koje su neujednačene po znanju (eng. multilevel groups), tzv. osobenosti ličnosti (eng. personality factors), među kojima su i: inhibicija, samopouzdanje, voljnost za preuzimanjem rizika, introvertnost ili, pak, ekstrovertnost, anksioznost, te mnoge druge [5] , koje nastavnika dovode u položaj u kojem je potrebno da posegne za različitim metodama, tehnikama, a neretko i da svoj pristup i model prenošenja znanja učini eklektičnim, kako bi odgovorio svim potrebama nastavne grupe.
S druge strane, procesi u vezi sa podučavanjem i učenjem/usvajanjem jezika struke, te jezika za akademske namene i očekivane tehnike koje bi bile sastavni deo tih procesa, manje su poznati obema grupama - nastavnicima i onima koji jezik uče, a u poređenju sa procesima usvajanja i nastave tzv. jezika za opšte namene koji je, kako je navedeno, neretko praćen brojnim izazovima sa kojima se susreću ne samo nastavnici, no i oni koji uče jezik. Otuda su napori obe grupe usložnjeni i, zasigurno, zahtevaju posebnu pažnju i pristup.

Uzimajući u obzir njihove ciljeve, jezik za posebne i akademske namene - u celosti, treba da bude posvećen pojedincu koji ga uči/usvaja, odnosno - zahteva pristup koji je upravo usmeren ka datom pojedincu (eng. learner-centred approach), ne bi li on, u budućnosti, naučeno mogao da primeni u okvirima svoje profesije, odnosno - za željene namene. U vezi sa tim, svakako da je važno, a za potrebe efektivnog usvajanja/učenja pojmova koji pripadaju obema oblastima - obratiti pažnju na sam kontekst u kojem će naučeni jezik, potonje biti korišćen, te na pravilno odgovaranje svim potrebama datog konteksta. Kako bi se navedeno postiglo, a nakon analize potreba pojedinca ili grupe, osmišljavanju kurseva/modela (engleskog) jezika za posebne i akademske namene potrebno je pristupiti sa velikom pažnjom.

Svakako, uloga nastavnika u procesu je od nemerljive važnosti, a slika koja sledi ilustruje upravo činioce koji su sastavni deo navedenog pristupa koji je usmeren ka učeniku (a koji je, u istim oblicima, sastavni deo nastave jezika za posebne i akademske namene).

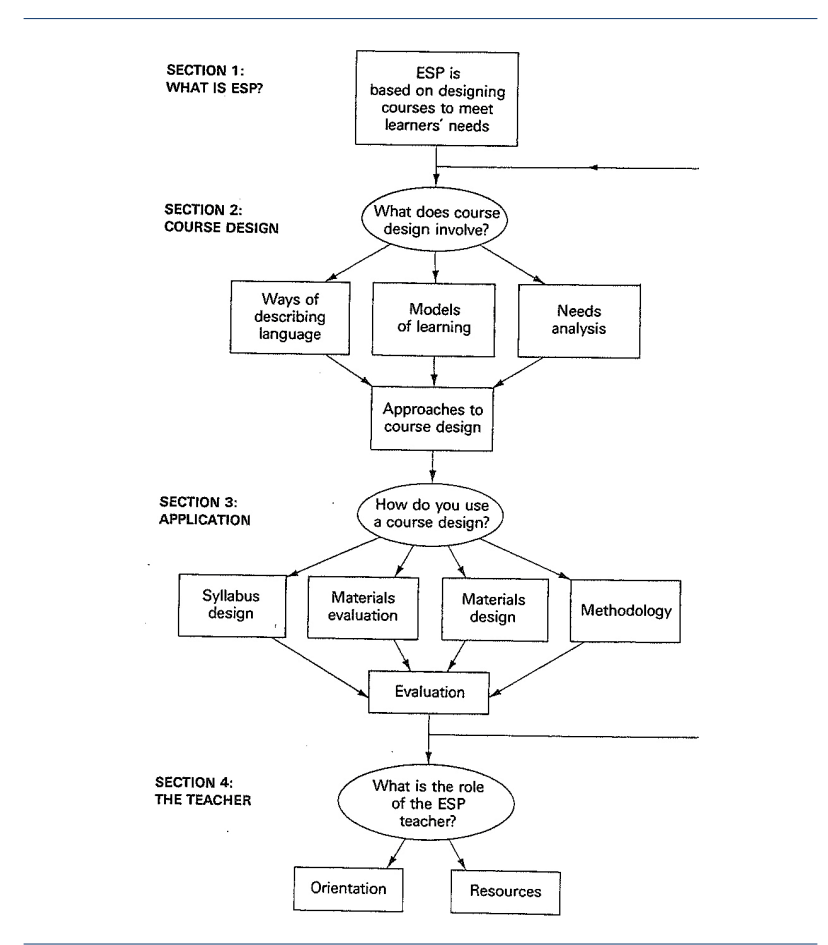

Fig. 2. Prikaz pristupa nastave jezika za posebne (akademske) namene koji je usmeren ka učeniku (preuzeto: [1, str. 3]) 
Ukoliko navedenome dodamo činjenicu da je, tokom proteklih decenija, utvrđeno pojavljivanje brojnih, različitih oblasti ljudskog delovanja/profesija u kojima postoji direktna potreba za efektivnom upotrebom engleskog jezika (za posebne namene), nedvosmisleno ćemo ukazati na važnost fenomena jezika struke i jezika za akademske namene. U isto vreme, postojanje pomenutog spektra, te, svakako, nezaustavljivo pojavljivanje novih profesija, koje uspevaju da pruže odgovore na nova kretanja društva, za nastavnike jezika donosi nova pitanja i nove nedoumice, a kada su u pitanju pristupi/ metodi/tehnike za koje će se odlučiti. Razgranatost ovog fenomena prikazana je na slikama koje slede, a, zapravo, predstavljaju, u okvirima nastave jezika u celosti, samo deo raspona jezika upotrebljenog u posebne svrhe:

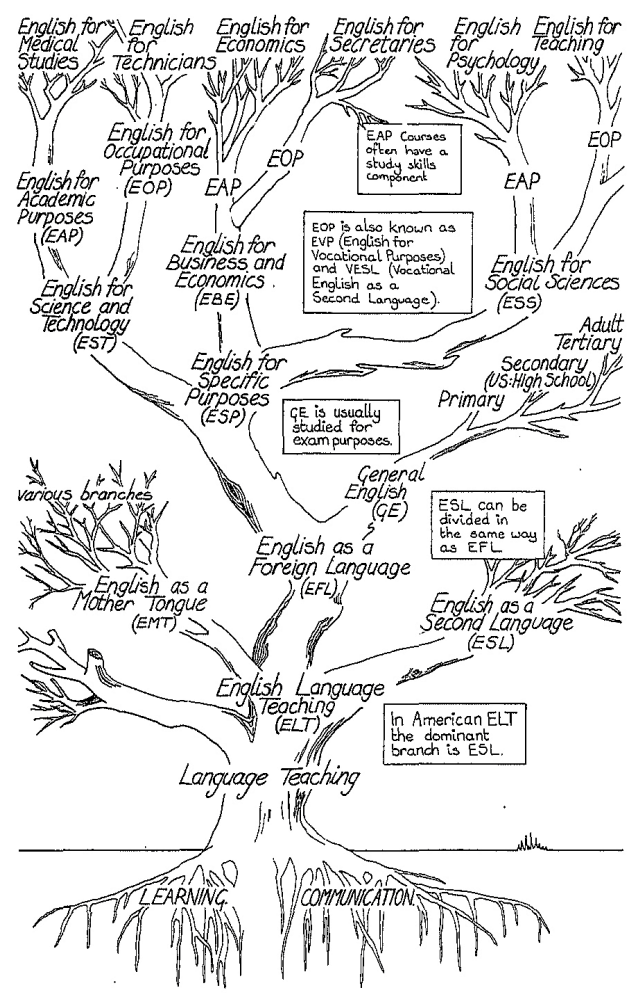

Fig. 3. Prikaz stabla - koncepta nastave jezika (preuzeto: [1, str. 17])

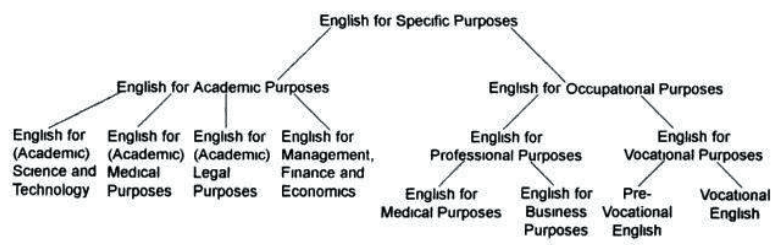

Fig. 4. Prikaz klasifikacije engleskog jezika za akademske namene i potrebe struke/radnog mesta (preuzeto: [2, str. 6])

\section{ESP I EAP - MESTO U AKADEMSKOM KONTEKSTU ${ }^{1}$}

Sistem visokog obrazovanja u Srbiji, ali i u zemljama iz regiona, zasigurno, uključuje i realizaciju studija na jeziku koji je, tokom proteklih decenija, dobio status jezika sa najviše govornika ikada - engleskom jeziku. Ovakva internacionalizacija visokog obrazovanja, kao što je slučaj sa istim fenomenom širom sveta - dovela je veće upotrebe engleskog jezika za različite namene. $\mathrm{Na}$ ime, visokoškolske institucije, prateći savremene tokove i osluškujući potrebe svojih studenata, kao i tržišta čiji će deo, po diplomiranju, postati, jesu osetili potrebu za tim i, u svoje nastavne planove i programe, uvrstile, najpre, tzv. jezik struke, odnosno - jezik za posebne namene, ali i jezik za akademske namene.

Status jezika struke, te jezika za akademske namene, a u okviru sistema visokog obrazovanja u republici Srbiji, ali i u zemljama u regionu (primarno - Hrvatska, Bosna i Hercegovina i Crna Gora), nije, u ovom trenutku, čini se, dovoljno jasan i sasvim ujednačen. Univerziteti, odnosno - fakulteti, kao njihov sastavni deo, pojedinačno, prateći osobenosti svojih studijskih programa, definišu izbor, ali i kvalitet i kvantitet nastave jezika stranog jezika, te jezika struke, odnosno jezika za posebne namene.

Ono što je, pak, sigurno jeste da, u ovom trenutku, engleski jezik uzima primat, a kada je u pitanju nastava jezika struke - te da je izučavanje drugih stranih jezika, u ovom obliku, odnosno - sa stanovišta stručnog jezika, manje uobičajeno, a na primeru najvećeg broja visokoškolskih ustanova iz zemlje i regiona.

Međutim, ni sam status engleskog jezika, za opšte namene, a koji se izučava u okviru nematičnih fakulteta/ katedri (svih onih koji nisu filološkog usmerenja), varira. Naime, ECTS vrednosti dodeljena predmetima koji u svojoj podlozi imaju izučavanje engleskog jezika, razlikuje se, neretko i značajno, a kada su u pitanju studijski programi visokoškolskih institucija iz zemlje i regiona (raspon pripadajućih ECTS vrednosti je 2-8), a situacija je srodna i kada je u pitanju engleski jezik za posebne namene.

Takođe, što se tiče pripadajućeg fonda časova, namenjenih jeziku (bilo ono za opšte, bilo onom za posebne namene), ne možemo reći da postoji ujednačenost - bez obzira na to da li se radi o srodnim ili, pak, nesrodnim usmerenjima/studijskim programima (raspon časova namenjenih stranom jeziku jeste 3-6 časova nastave, na nedeljnom nivou).

1 Podaci izloženi na Tribini o položaju stranih jezika struke u visokoškolskom obrazovanju, Društvo za strane jezike i književnosti Srbije, 23.02.2017. 
Činjenica da se jezik, per se, na univerzitetima, odnosno fakultetima koji su njihov sastavni deo, izučava u trajanju od jednog, pa do čak osam semestara - za nastavnike i sve one koji uče jezik predstavlja poseban izazov, posebno ukoliko navedenom dodamo i status predmeta u vezi sa jezikom - koji može biti obavezan ili izborni. Ukoliko se ponovo osvrnemo na svojevrnu analizu potreba, te na pristup koji je usmeren ka učeniku - zasigurno je da će neujednačenost, odnosno navedeni raspon, a kada je u pitanju vreme namenjeno učenju jezika, umnogome uticati na same ishode i mogućnost postizanja željenih ciljeva.

S obzirom na to da, kako jezik struke, tako i jezik za akademske namene, koji, u ovom trenutku, ne pronalazi zasebno mesto u okviru studijskih programa na univerzitetima u zemlji i regionu, no se izučava kao jedan od segmenata jezika za posebne namene, na svojevrstan način, jesu namenjeni onima koji već poseduju određena znanja u vezi sa jezikom, a da se nastavnici, u praksi, kontinuirano susreću sa grupama neujednačenim po znanju (eng. multilevel classes), postavlja se pitanje u kojoj meri i da li su, zapravo, uopšte vidljive granice između opšteg i jezika za posebne i akademske namene, te da li se nastavnici mogu, a ukoliko žele napredak onih koje podučavaju, osloniti samo na ograničen broj metoda, nastavnih materijala i sredstava ili je, pak, njihova uloga, u ovom procesu, višeslojna.

Pitanja od važnosti, najpre, za same nastavnike, ali sve izučavaoce jezika za posebne i akademske namene, uzimajući u obzir trenutni status jezika struke i jezika za posebne namene, jeste i odabir samih nastavnih materijala - a koji će, svojom strukturom i sadržajem, pružiti sve dogovore na potrebe pojedinaca, grupe, kao i savremenih kretanja u okvirima struke na koju se odnose. $\mathrm{U}$ isto vreme, na pomenutoj raskrsnici koja povezuje jezik za opšte, s jedne, i posebne, te akademske namene, s druge strane, nastavnici se suočavaju sa nedoumicama koje se odnose na njihovo poznavanje materije o kojoj je reč - na poznavanje osobenosti struke čiji jezik prenose, što otvara pitanje posvećivanja više pažnje ovom fenomenu i u okviru studijskih programa koji obrazuju buduće nastavnike jezika.

\section{ZAKLJUČAK}

Engleski jezik za posebne namene, kao i jezik za akademske namene, kao jedan od njegovoih oblika, srodan po svojim brojnim osobinama, u svetu nastave i učenja jezika su zauzeli svoje mesto sredinom prošlog veka, a svoju poziciju u da tim okvirima, s protokom vremena, čine sve značajnijom. Međutim, i pored toga što su visokoškolske institucije u zemlji i regionu prepoznale postojanje i važnost fenomena jezika za posebne i akademske namene, njegov status i pristup njegovom izučavanju, još uvek, nije sasvim jasno definisan i ujednačen. Otuda, s ciljem postizanja ciljeva navedenog fenomena, odnosno - efektivne upotrebe svih njegovih činilaca, jezik za posebne i akademske namene može i treba da ima prominentiju ulogu u akademskom okruženju, koja će, $u$ isto vreme, biti ispraćena i podržana sistematičnim pristupom u vezi sa njegovim formalnim karakteristikama.

\section{LITERATURA}

[1] T. Hutchinson, and A. Waters, English for Specific Purposes: A Learning-centred Approach. Cambridge: Cambridge University Press, 1987.

[2] T. Dudley-Evans, Developments in English for Specific Purposes: A Multilingual Disciplinary Approach. Cambridge: Cambridge University Press, 1998.

[3] K. Hyland, English for Academic Purposes. London: Routledge, 2006.

[4] J. C. Richards, and T.S. Rodgers, Approaches and Methods in Language Teaching. Cambridge: Cambridge University Press, 2014.

[5] D. Brown, Principles of Language Learning and Teaching. White Plains, NY: Pearson, 1994. 